Jurnal Agro 8(1), 2021

\title{
DAYA GABUNG DAN AKSI GEN KOMPONEN HASIL JAGUNG PROLIFIK HASIL TINGGI MENGGUNAKAN ANALISIS LINE X TESTER
}

\section{COMBINING ABILITY AND GENE ACTION OF YIELD COMPONENT IN THE HIGH YIELD PROLIFIC MAIZE USING LINE X TESTER ANALYSIS}

\author{
Roy Efendi, Slamet Bambang Priyanto*, M. Azrai \\ Balai Penelitian Tanaman Serealia \\ Jalan Dr Ratulangi 274 Maros Sulawesi Selatan 90512 \\ *Korespondensi: s.bambangpriyanto@gmail.com
}

Diterima : 04 Agustus 2020 / Disetujui 13 Juni 2021

\begin{abstract}
ABSTRAK
Peningkatan produktivitas jagung dapat dilakukan melalui perakitan varietas jagung yang memiliki tingkat prolifikasi tinggi. Ketersediaan galur-galur yang memiliki tingkat prolifikasi tinggi dan daya gabung yang baik akan memberikan peluang besar dalam perakitan jagung hibrida prolifik dengan hasil tinggi. Penelitian ini bertujuan memilih galur-galur prolifik yang memiliki daya gabung yang baik pada karakter prolifikasi dan mengevaluasi tingkat prolifikasi dan produktivitas jagung hibrida yang dibentuk dari galur-galur tersebut serta mengetahui aksi gen yang berperan pada karakter komponen hasil. Percobaan dilakukan dua tahap yaitu pembentukan hibrida dari galur-galur prolifik dengan metode testcross dan evaluasi hibrida yang terbentuk dengan menggunakan rancangan alfa lattice dengan tiga ulangan. Hasil penelitian menunjukkan galur G7 memiliki nilai daya gabung umum yang baik untuk karakter persentase tanaman prolifik. Hibrida G35/G102612 merupakan hibrida uji dengan persentase tanaman prolifik tertinggi 55,8\%. Hibrida G7/Mal03 dengan hasil biji 12,9 $\mathrm{t}$ ha ${ }^{-1}$ dan persentase tanaman prolifik 53,9\% merupakan jagung hibrida prolifik dengan hasil tinggi. Aksi gen non aditif lebih berperan dalam penampilan karakter komponen hasil pada jagung prolifik.
\end{abstract}

Kata kunci: daya gabung, line $x$ tester, prolifik.

\begin{abstract}
Maize productivity can be increased by improving maize varieties with high prolificacy. The adequate of high prolificacy lines with a good combining ability will provide great opportunities to form a high yield prolific maize. The research aimed to select the prolific line which has good combining ability on the prolificacy and evaluate the prolificacy and productivity of the hybrid maize from these lines and to know the gene action which plays role in the yield component characters. The research was carried out in two stages, i.e. the formation of hybrids from the prolific line using the testcross method and evaluation of hybrids using the alpha lattice design
\end{abstract}

ISSN : 2407-7933

Cite this as: Efendi R., Priyanto S B. \& Azrai M. (2021). Daya gabung dan aksi gen komponen hasil jagung profilik hasil tinggi menggunakan analisis line $X$ tester. Jurnal Agro, 8(1), 113-129. https://doi.org/10.15575/9209 
with three replications. The results showed that line $G 7$ had a good general combining ability for the percentage of prolific plants. Hybrid G35/G102612 was the test hybrid with the highest percentage of prolific plants of 55,8\%. Hybrid G7/ Mal03 which had the yield of $12,9 \mathrm{tha}^{-1}$ and percentage of prolific plants $53,9 \%$ was the prolific hybrid maize with the high yield. The nonadditive effect played the main role for yield component characters of prolific hybrid maize.

Keywords: combining ability, line $x$ tester, prolific.

\section{PENDAHULUAN}

Peningkatan kebutuhan jagung terkait meningkatnya jumlah penduduk dan berkembangnya usaha peternakan unggas petelur dan daging. Pada tahun 2017 tingkat partisipasi tertinggi konsumsi protein hewani asal ternak adalah telur yaitu sebesar $89,47 \%$ dan daging unggas sebesar 55,74\% (Widayati, 2018; Kementerian Pertanian, 2019). Berkembangnya usaha ternak unggas akan berdampak pada kebutuhan jagung dimana 45\% komposisi bahan baku pakan ternak unggas adalah biji jagung (Pelu et al., 2016).

Konsumsi jagung di Indonesia pada tahun 2018 mencapai 12,20 juta ton (Pusdatin, 2018), sedangkan rata-rata produksi jagung dalam negeri adalah 9,04 juta ton per tahun (Kementerian Pertanian Republik Indonesia, 2018). Pada periode yang sama, konsumsi rata-rata jagung adalah 11,14 juta ton per tahun kekurangan tersebut dipenuhi dengan impor jagung (Freddy et al., 2018). Peningkatan produksi jagung merupakan upaya untuk mencukupi kebutuhan jagung di Indonesia. Salah satu upaya peningkatan produksi jagung adalah memaksimalkan potensi genetik jagung yang salah satu diantaranya karakter prolifik dimana jagung yang menghasilkan lebih dari satu tongkol dalam satu tanaman.

Tanaman jagung berasal dari domestikasi tanaman teosinte (Zea mays subsp. parviglumis) yang memiliki banyak tongkol/tanaman (Webster et al., 2011; Yang et al., 2016; Khatefov \& Appaev, 2019). Selanjutnya Al-Naggar et al. (2012) melaporkan bahwa sifat prolifik pada jagung dikendalikan oleh suatu aksi gen sederhana. Selanjutnya (Wills et al., 2013) mengkonfirmasi bahwa mayor QTL (prol1.1) terdeteksi di lengan pendek kromosom 1 mengendalikan sifat prolifikasi jagung. Menurut Prasanna (2012) potensi genetik prolifik umumnya dimiliki oleh jenis jagung lokal. Fan et al. (2012) melaporkan bahwa potensi hasil pada jagung komposit dapat ditingkatkan mencapai 32 persen setelah 10 siklus seleksi untuk sifat prolifiknya. Lebih lanjut hasil penelitian Tinca et al. (2016) dan Ross et al. (2020) menunjukkan bahwa jagung hibrida yang prolifik cenderung memberikan hasil lebih tinggi dibanding jagung non prolifik. Penambahan hasil tersebut ditunjang dengan bobot dan jumlah biji yang besar per tanaman terutama yang disumbangkan oleh tongkol sekundernya (tongkol ke-2).

Varietas komersial jagung prolifik yang tersedia di Indonesia saat ini hanya varietas Bisi 2, namun produktivitasnya lebih rendah dibanding hibrida non prolifik. Penelitian uji multilokasi beberapa jagung hibrida di lima lokasi menunjukkan bahwa rata-rata produktivitas varietas Bisi 2 rata-rata $6,85 \mathrm{t}$ $\mathrm{ha}^{-1}$ nyata lebih rendah dibanding varietas AS-1 dan Bima 3 yang tergolong non prolifik dengan hasil masing-masing $7,68 \mathrm{t} \mathrm{ha}^{-1}$ dan $8,02 \mathrm{t} \mathrm{ha}^{-1}$ (Priyanto et al., 2016). 
Tanaman jagung prolifik idealnya memiliki tongkol dua yang terletak di nodus berbeda serta memiliki ukuran tongkol sama antara tongkol primer (Tongkol ke-1) dan sekunder (Tongkol ke-2). Namun umumnya genotipe jagung yang memiliki potensi genetik prolifik memiliki ukuran tongkol ke-1 dan ke-2 yang tidak seragam, bahkan tongkol tongkol ke-2 tidak menghasilkan biji (baren), sehingga perlu perbaikan dan pemantapan. Menurut Penny (2018) perbaikan dan pemantapan galur-galur jagung yang prolifik sebaiknya dilakukan dengan seleksi secara langsung pada karakter prolifik baik kondisi optimum maupun kepadatan populasi tinggi.

Ketersediaan galur-galur yang memiliki tingkat prolifikasi tinggi dan daya gabung baik akan memberikan peluang besar untuk memperoleh jagung hibrida prolifik dengan hasil yang tinggi (Adebayo \& Menkir 2015; Meseka et al., 2011, 2016 ; Efendi et al., 2020). Namun tingkat ketersediaannya masih terbatas. Menurut Qosim (2018) penyediaan plasma nutfah sebagai bahan baku pemuliaan tanaman dapat dilakukan antara lain dengan melakukan introduksi dan persilangan. Balai Penelitian Tanaman Serealia telah membentuk galur-galur prolifik yang dibentuk dari populasi prolifik hasil rekombinasi hibrida prolifik asal India dan China. Seleksi, perbaikan dan pemantapan galur-galur prolifik diarahkan dengan kemampuan menghasilkan tanaman yang prolifik lebih dari $75 \%$. Namun galur tersebut belum teridentifikasi daya gabungnya terutama untuk karakter prolifikasi dan daya hasil. Oleh karena itu perlu adanya suatu pengkajian daya gabung galur tersebut pada karakter prolifikasi dan daya hasil. Informasi daya gabung umum (DGU) dan daya gabung khusus (DGK) galur tersebut sangat penting dalam perakitan jagung hibrida (Sutoro \& Setyowati, 2015; Harriman \& Nwammadu, 2016).

Analisis daya gabung merupakan salah satu cara yang ampuh dalam mengidentifikasi kombinasi tetua terbaik. Informasi tentang nilai DGU dan DGK digunakan untuk memilih tetua baik untuk pembentukan hibrida maupun varietas sintetik (Rahaman, 2016). Salah satu metode Identifikasi daya gabung adalah dengan mengunakan metode line $x$ tester. Penggunaan metode persilangan line $x$ tester bertujuan untuk mengidentifikasi galur (line) yang memiliki daya gabung yang baik untuk digunakan secara efektif dalam program pengembangan galur dan pembentukan hibrida. Metode line $x$ tester mampu memperkirakan nilai daya gabung umum dan daya gabung khusus pada suatu kombinasi persilangan (Kamara et al., 2014). Lebih lanjut metode ini juga mampu mengestimasi pengaruh gen aditif dan nonaditif terhadap penampilan sifat tersebut (Estakhr \& Heidari, 2012). Penggunaan metode line $x$ tester lazim digunakan pada beberapa komoditas. Hibbiny et al. (2019) menggunakan metode line $x$ tester guna mengetahui DGU dan DGK komponen hasil dan sifat serat kapas. Untuk tanaman bunga matahari oleh Rameeh \& Andarkhor (2017) dan Tyagi et al. (2018) serta pada tanaman jagung oleh Makkulawu et al. (2007), Azrai \& Mejaya (2014), Ruswandi et al. (2015); Efendi et al. (2017).

Tujuan penelitian ini adalah memilih galur-galur prolifik dengan daya gabung baik untuk karakter prolifikasi serta mengevaluasi tingkat prolifikasi dan produktivitas jagung hibrida yang terbentuk dari galur-galur tersebut serta mengetahui aksi gen yang berperan pada komponen hasil. informasi ilmiah yang diperoleh akan sangat berguna bagi pengembangan jagung 
hibrida prolifik dengan produksi tinggi di Indonesia.

\section{BAHAN DAN METODE}

Pembentukan hibrida dilakukan dengan metode line $x$ tester di kebun percobaan Maros, Balai Penelitian Tanaman Serealia, Sulawesi Selatan pada bulan April-Juli 2017. Pembentukan jagung hibrida prolifik dilakukan dengan menggunakan 33 galur betina (line) dengan potensi prolifik tinggi dan tiga galur jantan (tester) yang memiliki daya prolifikasi tinggi yaitu CY16, G102612, dan Mal 03 (Tabel 1). Galur Tetua betina dibentuk dari populasi prolifik hasil rekombinasi dari jagung hibrida prolifik asal India dan China. Seleksi karakter prolifik dilakukan dengan melakukan silang dalam hanya pada tongkol kedua.

Hibrida yang terbentuk dari line $x$ tester sebanyak 99 genotipe jagung hibrida prolifik. Hibrida tersebut dievaluasi pada bulan Juni-September 2017 di Kebun
Percobaan Balai Penelitian Tanaman Serealia, Bajeng, Gowa, Sulawesi Selatan. Varietas pembanding yang digunakan adalah jagung hibrida prolifik yaitu Bisi 2 dan Nakulasadewa 29 (Nasa 29) yang merupakan varietas jagung prolifik dari perusahaan benih multinasional dan Balai Penelitian Tanaman Serealia serta varietas non prolifik yaitu P 27 multinasional. Rancangan percobaan yang digunakan untuk evaluasi 112 hibrida prolifik adalah rancangan alpha lattice dengan tiga ulangan dimana tiap ulangan terdiri dari dua blok. Setiap genotipe hibrida ditanam 2 baris dengan panjang baris $5 \mathrm{~m}$ dan jarak tanam $75 \times 20 \mathrm{~cm}$.

Pemupukan diaplikasikan dua kali. Pemupukan pertama dilakukan saat tanaman berumur 11 hari setelah tanam (hst) dengan takaran $400 \mathrm{~kg} \mathrm{ha}^{-1}$ phonska dan $100 \mathrm{~kg} \mathrm{ha}^{-1}$ urea. Pemupukan kedua dilakukaan saat tanaman berumur $42 \mathrm{Hst}$ dengan takaran pupuk $120 \mathrm{~kg} \mathrm{ha}^{-1}$ urea.

Tabel 1. Galur-galur prolifik tetua betina (line) dan galur tetua jantan (tester)

\begin{tabular}{|c|c|c|c|c|c|}
\hline No. & galur & Pedigree & No. & Galur & Pedigree \\
\hline & \multicolumn{2}{|c|}{ Galur tetua betina (line) } & 19 & G19 & СiT2-72-1-2-1-1 \\
\hline 1 & G1 & СіT2-21-1-1-1-1 & 20 & G20 & СіТ2-72-2-1-1-1 \\
\hline 2 & G2 & СіТ2-21-2-1-1-2 & 21 & G21 & CiT2-80-1-1-2-1 \\
\hline 3 & G3 & СiT2-21-3-1-1-1 & 22 & G22 & СіТ2-80-2-1-1-1 \\
\hline 4 & G4 & СіT2-21-4-1-2-1 & 23 & G23 & СіТ2-84-1-1-1-2 \\
\hline 5 & G5 & Сіт2-21-5-1-1-1 & 24 & G24 & СіТ2-84-2-1-1-1 \\
\hline 6 & G6 & СіT2-21-6-2-1-1 & 25 & G25 & СіТ2-90-1-2-1-1 \\
\hline 7 & G7 & СіT2-21-7-1-1-1 & 26 & G26 & СіТ2-94-1-1-1-1 \\
\hline 8 & G8 & СіT2-22-1-2-1-2 & 27 & G27 & СіТ2-96-1-1-1-1 \\
\hline 9 & G9 & СіT2-36-1-1-1-2 & 28 & G28 & Сіт2-96-2-1-1-1 \\
\hline 10 & G10 & СіT2-36-2-1-1-1 & 29 & G30 & Сіт2-100-2-1-1-1 \\
\hline 11 & G11 & СіT2-36-3-1-1-1 & 30 & G32 & Сіт2-105-2-1-1-1 \\
\hline 12 & G12 & Сіт2-36-4-1-2-1 & 31 & G33 & Сіт2-119-1-1-1-2 \\
\hline 13 & G13 & СіT2-36-5-1-1-1 & 32 & G34 & Сіт2-138-1-2-2-1 \\
\hline 14 & G14 & СіT2-39-1-2-1-1 & 33 & G35 & СіT2-138-2-1-1-1 \\
\hline 15 & G15 & СiT2-43-1-1-1-1 & & \multicolumn{2}{|c|}{ Galur tetua jantan(tester) } \\
\hline 16 & G16 & СiT2-43-2-1-1-2 & 1 & \multicolumn{2}{|l|}{ CY6 } \\
\hline 17 & G17 & СiT2-52-1-1-2-1 & 2 & \multicolumn{2}{|c|}{ G102612 } \\
\hline 18 & G18 & СіТ2-52-2-1-1-1 & 3 & \multicolumn{2}{|c|}{ Mal03 } \\
\hline
\end{tabular}


Parameter yang diamati adalah persentase prolifik, bobot tongkol kupasan, diameter tongkol, panjang tongkol, hasil biji panen dengan kadar air biji 15\%, dihitung dengan mengkonversi hasil panen tongkol kupasan basah per plot dengan menggunakan rumus:

$$
\begin{aligned}
& \text { Hasil }\left(\mathrm{t} h a^{-1}\right) \\
& =\frac{10.000 m^{2}}{L P} \times \frac{100-K A}{100-15} \times \frac{B T P}{1000} \times S P
\end{aligned}
$$

dimana $\mathrm{LP}=$ luas panen petakan $\left(\mathrm{m}^{2}\right), \mathrm{KA}=$ kadar air biji panen, BTP = bobot tongkol kupasan panen $(\mathrm{kg})$,

$\mathrm{SP}=$ redemen biji yang dihitung dengan rumus,

$S P=\frac{\text { Botot biji panen }}{\text { Botot tongkol panen }}$ (Sujiprihati et al., 2006)

Analisis daya gabung umum (DGU) dan daya gabung khusus (DGK) dihitung merunut metode Singh dan Chaudhary (1979) dengan rumus :

$g_{i}=\frac{x_{i}}{\operatorname{tr}}-\frac{x_{. .}}{l t r}, g_{j}=\frac{x_{j}}{l r}-\frac{x_{. .}}{l t^{\prime}}$

$s_{i j}=\frac{x_{i j}}{r}-\frac{x_{i}}{t r}-\frac{x_{j}}{l r}+\frac{x_{. .}}{l t r}$.

Dimana

$\mathrm{g}_{\mathrm{i}}=\mathrm{DGU}$ line, $\mathrm{g}_{\mathrm{j}}=\mathrm{DGU}$ tester, $\mathrm{S}_{\mathrm{ij}}=$ DGK persilangan line ke-i $x$ tester $k e-j, x_{i}=j u m l a h$ total line ke-i, $\mathrm{x}_{\mathrm{j}}=\mathrm{jumlah}$ total tester $\mathrm{ke}-\mathrm{j}, \mathrm{x}_{\mathrm{ij}}=\mathrm{jumlah}$ persilangan line ke-i $x$ tester $k e-j, x_{. .}=G$ rand Total, I=jumlah line, $\mathrm{t}=$ jumlah tester, dan $r=j u m l a h$ ulangan

Untuk menentukan beda nyata DGU dan DGK terhadap rata-rata umum digunakan uji t. Analisis daya gabung dilakukan dengan menggunakan perangkat lunak AGD-R
(Analysis of Genetic Designs in R) Version 3.0 dari CYMMIT.

Analisis korelasi tiap variabel dilakukan untuk mengetahui variabel-variabel yang mendukung peningkatan produktivitas jagung hibrida melalui prolifikasi tinggi. Nilai korelasi dihitung dengan menggunakan rumus

$$
r=\frac{\sum X Y-\frac{\sum X \sum Y}{n}}{\sqrt{\left(\sum X^{2}-\frac{\left(\sum X\right)^{2}}{n}\right)} \sqrt{\left(\sum Y^{2}-\frac{\left(\sum Y\right)^{2}}{n}\right)}}
$$

Nilai parameter genetik diturunkan dari analisis ragam DGU dan DGK pada Tabel 2 menurut Singh \& Chaudhary (1979).

Tabel 2. Analisis Ragam DGU dan DGK

\begin{tabular}{lll}
\hline SK & $\mathrm{Db}$ & $\mathrm{KT}$ \\
\hline Ulangan & $(\mathrm{u}-1)$ & \\
Hibrida & $(\mathrm{Ixt})-1$ & \\
Line & $\mathrm{I}-1$ & $\mathrm{KT}$ \\
Tester & $\mathrm{t}-1$ & $\mathrm{KT}_{\mathrm{t}}$ \\
Line $\mathrm{x}$ tester & $(\mathrm{I}-1) \mathrm{x}(\mathrm{t}-1)$ & $\mathrm{KT}_{\mathrm{Ixt}}$ \\
Galat & $(\mathrm{u}-1)((\mathrm{lxt})-1)$ & $\mathrm{KT}_{\varepsilon}$ \\
\hline
\end{tabular}

$\sigma^{2} \mathrm{DGU}=\mathrm{Cov} \mathrm{HS}$

$\operatorname{Cov} \mathrm{HS}=\frac{1}{(\mathrm{r}(2 \mathrm{lt}-\mathrm{l}-\mathrm{t})}\left[\frac{(\mathrm{l}-1) \mathrm{KT}_{\mathrm{l}}+(\mathrm{t}-1) \mathrm{KT}_{\mathrm{t}}}{\mathrm{l}+\mathrm{t}-2}-\mathrm{KT}_{\mathrm{lxt}}\right]$

$\sigma^{2} \mathrm{DGK}=\frac{\mathrm{KT}_{\mathrm{lxt}}-\mathrm{KT}_{\varepsilon}}{\mathrm{r}}$

$\sigma^{2} \mathrm{DGU}=\left(\frac{1+F}{4}\right) \sigma^{2} A, \sigma^{2} \mathrm{DGK}=\left(\frac{1+\mathrm{F}}{2}\right)^{2} \sigma^{2} \mathrm{D}$

$\sigma^{2} \varepsilon=\mathrm{KT} \varepsilon$

$\mathrm{F}=1$ Karena line dan tester semuanya adalah galur.

Nilai heritabilitas arti luas dihitung berdasarkan rumus

$\mathrm{h}_{\mathrm{b}}^{2}=\frac{\sigma^{2} \mathrm{~A}+\sigma^{2} \mathrm{D}}{\sigma^{2} \mathrm{P}}$ 
Nilai heritabilitas arti sempit dihitung berdasarkan rumus

$\mathrm{h}_{\mathrm{ns}}^{2}=\frac{\sigma^{2} \mathrm{~A}}{\sigma^{2} \mathrm{P}}$

dimana $\sigma_{\mathrm{P}=}^{2} \sigma_{\mathrm{A}+}^{2} \sigma_{\mathrm{D}+}^{2} \sigma^{2} \varepsilon$ (Sharma, 1988)

Selanjutnya nilai $\mathrm{h}_{\mathrm{b}}^{2}$ dikelompokkan sebagai berikut:

$\mathrm{h}_{\mathrm{b}}^{2}>0,5$ tinggi, $0,2<\mathrm{h}_{\mathrm{b}}^{2}<0,5$ sedang, $\mathrm{h}_{\mathrm{b}}^{2}<$ 0,2 rendah (Stansfield, 1983).

\section{HASIL DAN PEMBAHASAN}

Analisis ragam menunjukkan perbedaan yang nyata antar galur betina (line) dan galur jantan (tester) untuk variabel persentase tanaman prolifik, hasil dan komponen hasil (Tabel 3). Perbedaan yang nyata antar galur menunjukkan adanya keragaman karakter persentase tanaman prolifik, hasil dan komponen hasil sehingga dapat melakukan seleksi atau pemilihan tetua dalam program perakitan varietas jagung hibrida dengan karakter prolifikasi dan hasil yang tinggi.

Galur G7 memiliki nilai daya gabung umum yang nyata positif untuk karakter persentase tanaman prolifik dan hasil biji tongkol ke-2 masing-masing dengan nilai daya gabung yaitu 23,4 dan 0,8 (Tabel 4). $\mathrm{Hal}$ tersebut menunjukkan galur G7 memiliki potensi untuk menurunkan sifat prolifikasi dan hasil biji tongkol ke-2 yang cukup baik, sehingga galur tersebut dapat digunakan sebagai tetua untuk program perakitan varietas jagung hibrida prolifikasi tinggi.

Tabel 3. Nilai kuadrat tengah analisis ragam variabel persentase tanaman prolifik, hasil, panjang tongkol dan diameter tongkol antara 33 galur betina (line) dengan 3 galur jantan (tester)

\begin{tabular}{lccccccccc}
\hline \multirow{2}{*}{$\begin{array}{c}\text { Sumber } \\
\text { keragaman }\end{array}$} & $\begin{array}{c}\text { persentase } \\
\text { tanaman } \\
\text { prolifik }\end{array}$ & Hasil & & \multicolumn{2}{c}{ Hasil dari tongkol } & \multicolumn{2}{c}{ Panjang tongkol } & \multicolumn{2}{c}{ Diameter tongkol } \\
\cline { 5 - 9 } & & & pertama & Kedua & pertama & Kedua & pertama & kedua \\
\hline Ulangan & 1196,049 & 1,865 & 5,071 & 0,839 & 7,1805 & 21,974 & 20,313 & 364,238 \\
Hibrida & $448,538^{* *}$ & $4,254^{* *}$ & $3,902^{* *}$ & $0,566^{* *}$ & $2,1283^{* *}$ & $31,3276^{* *}$ & $8,7788^{* *}$ & $278,818^{*}$ \\
Line & $739,445^{* *}$ & $5,861^{* *}$ & $5,773^{* *}$ & $0,794^{* *}$ & $2,5006^{* *}$ & $43,3977^{* *}$ & $16,744^{* *}$ & $342,353^{*}$ \\
Tester & $1297,151^{* *}$ & $12,821^{* *}$ & $17,141^{* *}$ & $0,643^{*}$ & $21,911^{* *}$ & $196,239^{* *}$ & $7,4859^{*}$ & $736,675^{*}$ \\
Line:Tester & $276,566^{* *}$ & $3,183^{* *}$ & $2,553^{* *}$ & $0,449^{* *}$ & $1,3239^{* *}$ & $20,1391 \mathrm{tn}$ & $4,8366^{* *}$ & $232,743 \mathrm{tn}$ \\
Galat & 116,706 & 0,871 & 0,619 & 0,163 & 0,7391 & 18,8406 & 1,4492 & 200,566
\end{tabular}

Keterangan: **berpengaruh nyata pada tingkat probabilitas $<0,01$ dan *berpengaruh nyata pada tingkat probabilitas $<0,05$.

Galur G32 memiliki daya gabung umum yang nyata positif untuk karakter hasil biji $(2,3)$ dan diameter tongkol pertama $(3,3)$ (Tabel 4). Galur G32 dapat digunakan dalam perakitan varietas jagung hibrida tongkol tunggal dengan hasil tinggi. Daya gabung umum (DGU) dari suatu galur dikendalikan oleh gen aditif yang dapat diturunkan ke generasi berikutnya (Melchinger, 2010;
Harriman \& Nwammadu, 2016). Nilai DGU merupakan kriteria utama dalam memilih galur-galur potensial sebagai program pengembangan galur dan pembentukan jagung hibrida.

Galur G11, G15 dan G35 yang berpasangan dengan galur G102612 (tester) memiliki nilai daya gabung khusus (DGK) yang nyata positif untuk karakter 
persentase tanaman prolifik masing-masing sebesar 16,8, 21,7, dan 27,8. Galur G7 juga memiliki nilai daya gabung khusus yang nyata positif dengan galur Mal03 untuk karakter persentase tanaman prolifik yaitu sebesar 20,0 (Tabel 5). Nilai daya gabung khusus yang nyata positif menunjukkan bahwa hibrida yang dibentuk dari pasangan galur tersebut memiliki persentase tanaman prolifik yang cukup besar. Hal tersebut dapat dilihat pada persentase tanaman prolifik pada hibrida G7/Mal03, G35/G102612, G15/ G102612 yang memiliki persentase tanaman prolifik berkisar 53,9-55,8\% tidak berbeda nyata dengan varietas Bisi 2 yang memiliki persentase prolifik 70,22\% (Tabel 5).

Tabel 4. Nilai daya gabung umum galur betina (line) dan galur jantan (tester) pada variabel persentase tanaman prolifik, hasil biji, panjang tongkol dan diameter tongkol

\begin{tabular}{|c|c|c|c|c|c|c|c|c|c|}
\hline \multirow[b]{3}{*}{ No. } & \multirow{3}{*}{$\begin{array}{c}\text { Galur } \\
\text { betina } \\
\text { (Line) }\end{array}$} & \multicolumn{8}{|c|}{ Nilai daya gabung umum pada variabel } \\
\hline & & \multirow[b]{2}{*}{$\begin{array}{c}\text { Persentase } \\
\text { tanaman } \\
\text { prolifik }\end{array}$} & \multicolumn{3}{|c|}{ Hasil biji } & \multirow[b]{2}{*}{$\begin{array}{c}\text { Panjang } \\
\text { tongkol } \\
\text { ke-1 }\end{array}$} & \multirow[b]{2}{*}{$\begin{array}{l}\text { Panjang } \\
\text { tongkol } \\
\text { ke-2 }\end{array}$} & \multirow[b]{2}{*}{$\begin{array}{c}\text { Diameter } \\
\text { Tongkol } \\
\text { ke-1 }\end{array}$} & \multirow[b]{2}{*}{$\begin{array}{c}\text { Diameter } \\
\text { Tongkol } \\
\text { ke-2 }\end{array}$} \\
\hline & & & $\begin{array}{c}\text { Akumulasi } \\
\text { tongkol ke-1 } \\
\text { dan ke-2 }\end{array}$ & $\begin{array}{c}\text { Tongkol } \\
\text { ke }-1\end{array}$ & $\begin{array}{c}\text { Tongkol } \\
\text { ke }-2\end{array}$ & & & & \\
\hline 1 & G1 & 4,3 & 1,0 & 0,8 & 0,2 & 0,1 & 1,1 & $-0,7$ & 4,4 \\
\hline 2 & G2 & $-1,5$ & 0,2 & 0,2 & $-0,1$ & 0,2 & 1,6 & $-0,8$ & 3,2 \\
\hline 3 & G3 & $-11,9$ & 0,1 & 0,5 & $-0,4$ & 0,1 & $-2,1$ & 1,4 & $-7,2$ \\
\hline 4 & G4 & 0,8 & 0,8 & 0,8 & 0,0 & 0,4 & 0,8 & 0,2 & 3,1 \\
\hline 5 & G5 & 3,0 & $-0,4$ & $-0,5$ & 0,1 & 0,5 & 0,0 & $-1,0$ & $-4,2$ \\
\hline 6 & G6 & 4,1 & $-0,3$ & $-0,6$ & 0,2 & 0,9 & 1,0 & $-2,8^{*}$ & $-0,4$ \\
\hline 7 & G7 & $23,4^{*}$ & 1,4 & 0,6 & $0,8^{*}$ & 0,4 & 3,9 & $-1,0$ & 7,4 \\
\hline 8 & G8 & 13,9 & $-0,2$ & $-0,5$ & 0,4 & 0,2 & $4,7^{*}$ & $-0,7$ & 8,9 \\
\hline 9 & G9 & $-3,7$ & $-1,2$ & $-1,0$ & $-0,2$ & 0,1 & 2,6 & $-0,2$ & 6,7 \\
\hline 10 & G10 & 11,1 & $-0,9$ & $-1,1$ & 0,2 & 0,4 & 4,0 & $-1,8$ & 7,2 \\
\hline 11 & G11 & 14,7 & $-0,1$ & $-0,6$ & 0,5 & 0,2 & $-0,5$ & $-1,7$ & $-2,5$ \\
\hline 12 & G12 & 3,5 & $-0,4$ & $-0,5$ & 0,1 & 0,3 & 1,1 & 1,0 & 4,9 \\
\hline 13 & G13 & $-8,1$ & $-0,5$ & $-0,2$ & $-0,3$ & $-0,4$ & $-3,2$ & $-0,1$ & $-9,1$ \\
\hline 14 & G14 & 10,8 & $-0,6$ & $-0,9$ & 0,3 & $-0,9$ & 1,5 & $-1,1$ & 5,3 \\
\hline 15 & G15 & 15,8 & 0,1 & $-0,4$ & 0,5 & $-0,3$ & 1,2 & 0,3 & 5,8 \\
\hline 16 & G16 & $-1,6$ & 0,4 & 0,4 & 0,0 & $-0,4$ & $-0,9$ & $-0,2$ & 0,0 \\
\hline 17 & G17 & 5,7 & $-1,0$ & $-1,1$ & 0,1 & 0,1 & 1,8 & $-1,5$ & 4,9 \\
\hline 18 & G18 & $-4,1$ & $-1,3$ & $-1,1$ & $-0,2$ & 0,6 & $-1,6$ & $-2,4$ & $-4,6$ \\
\hline 19 & G19 & $-4,3$ & 0,7 & 0,9 & $-0,1$ & 0,7 & 0,0 & 1,5 & 4,8 \\
\hline 20 & G20 & 1,0 & 1,4 & 1,4 & $-0,1$ & 0,6 & 0,3 & 1,0 & 9,3 \\
\hline 21 & G21 & $-4,7$ & 0,8 & 1,0 & $-0,2$ & 0,6 & 1,9 & 0,8 & 4,9 \\
\hline 22 & $\mathrm{G} 22$ & $-10,2$ & $-0,7$ & $-0,4$ & $-0,3$ & $-1,1^{*}$ & $-4,2$ & $-1,0$ & $-9,8$ \\
\hline 23 & G23 & $-7,4$ & $-1,0$ & $-0,8$ & $-0,3$ & $-1,2^{*}$ & $-1,8$ & $-0,4$ & $-3,0^{*}$ \\
\hline 24 & G24 & $-0,1$ & 0,5 & 0,4 & 0,2 & $-0,4$ & 0,9 & $-0,5$ & 4,2 \\
\hline 25 & G25 & $-8,4$ & $-0,6$ & $-0,4$ & $-0,2$ & $-0,8$ & 0,1 & 0,7 & $-1,9$ \\
\hline 26 & G26 & $-10,8$ & $-0,5$ & $-0,2$ & $-0,3$ & $-0,2$ & $-1,1$ & 1,5 & $-5,1$ \\
\hline 27 & G27 & $-9,3$ & $-0,4$ & $-0,1$ & $-0,3$ & 0,1 & $-1,3$ & 1,4 & $-2,6$ \\
\hline 28 & G28 & $-4,6$ & $-0,3$ & $-0,1$ & $-0,2$ & 0,1 & $-1,8$ & $-0,2$ & $-4,3$ \\
\hline 29 & G30 & $-7,3$ & 0,8 & 1,0 & $-0,2$ & 0,2 & $-2,4$ & 1,7 & $-7,5$ \\
\hline 30 & G32 & $-11,1$ & $2,0^{*}$ & $2,3^{* *}$ & $-0,3$ & 0,3 & $-4,6 *$ & $3,3^{*}$ & $-14,6$ \\
\hline 31 & G33 & $-6,6$ & 0,1 & 0,3 & $-0,2$ & $-0,4$ & $-0,6$ & 1,2 & $-0,8$ \\
\hline 32 & G34 & $-6,0$ & $-0,5$ & $-0,2$ & $-0,3$ & $-0,1$ & $-1,7$ & 2,0 & $-8,7$ \\
\hline 33 & G35 & 9,8 & 0,5 & 0,0 & 0,5 & $-0,7$ & $-0,6$ & 0,3 & 1,7 \\
\hline & $\begin{array}{r}\text { Galur } \\
\text { (Tes }\end{array}$ & $\begin{array}{l}\text { jantan } \\
\text { ter) }\end{array}$ & & & & & & & \\
\hline 1 & $10-2612$ & 2,6 & $-0,2$ & $-0,2$ & 0,1 & 0,5 & 0,6 & $-0,3$ & 0,9 \\
\hline 2 & CY6 & 1,5 & $-0,3$ & $-0,2$ & 0,0 & $-0,1$ & 1,0 & 0,0 & 2,2 \\
\hline 3 & Mal03 & $-4,1$ & 0,4 & 0,5 & $-0,1$ & $-0,4$ & $-1,6$ & 0,3 & $-3,1$ \\
\hline
\end{tabular}


Sejumlah galur yang memiliki memiliki daya gabung khusus yang baik untuk karakter persentase tanaman prolifik seperti galur G11, G15, G35 dan G7, namun hanya galur $\mathrm{G} 7$ (G7/Mal03) yang memiliki nilai daya gabung khusus nyata positif $(1,2)$ untuk karakter hasil biji (Tabel 5). Galur G7 yang memiliki daya gabung yang baik untuk karakter prolifikasi dan hasil biji menunjukkan perbedaan yang nyata dibanding dengan galur-galur yang hanya memiliki daya gabung baik pada karakter prolifikasi seperti galur G35. Hibrida G7/Mal03 dan G35/G102612 yang memiliki persentase tanaman prolifik yang sama yaitu berkisar 54-55\%, menunjukkan hasil biji yang berbeda nyata dimana hibrida G7/Mal03 memiliki hasil 12,98 $\mathrm{t}$ ha $^{-1}$ sedangkan hibrida G7/Mal03 hanya 10,6 t ha ${ }^{-1}$ (Tabel 6).

Tabel 5. Nilai daya gabung khusus galur betina (line) dengan galur jantan (tester) pada variabel persentase tanaman prolifik dan hasil biji

\begin{tabular}{|c|c|c|c|c|c|c|c|c|c|c|c|c|c|}
\hline \multirow[t]{2}{*}{ No } & \multirow[t]{2}{*}{ Galur } & \multicolumn{3}{|c|}{$\begin{array}{c}\text { Persentase } \\
\text { tanaman prolifik }\end{array}$} & \multicolumn{3}{|c|}{$\begin{array}{c}\text { Hasil biji } \\
\text { dari akumulasi } \\
\text { tongkol ke-1 dan } 2\end{array}$} & \multicolumn{3}{|c|}{$\begin{array}{l}\text { Hasil biji dari } \\
\text { tongkol ke-1 }\end{array}$} & \multicolumn{2}{|c|}{$\begin{array}{l}\text { Hasil biji dari } \\
\text { tongkol ke-2 }\end{array}$} & \multirow[b]{2}{*}{ Mal03 } \\
\hline & & G102612 & CY6 & Mal03 & G102612 & CY6 M & Mal03 & G102612 & CY6 & Mal03 & G102612 & CY6 1 & \\
\hline 1 & G1 & 4,6 & 3,9 & $-8,5$ & 0,7 & $-0,6$ & $-0,1$ & 0,7 & $-0,6$ & $-0,1$ & 0,4 & 0,0 & $-0,4$ \\
\hline 2 & $\mathrm{G} 2$ & $-6,2$ & 9,5 & $-3,3$ & 0,7 & $-0,5$ & $-0,2$ & 0,7 & $-0,5$ & $-0,2$ & $-0,2$ & 0,3 & $-0,1$ \\
\hline 3 & G3 & $-2,6$ & $-0,4$ & 3,0 & $-0,9$ & 0,8 & 0,1 & $-0,9$ & 0,8 & 0,1 & $-0,1$ & 0,1 & 0,0 \\
\hline 4 & G4 & $-9,4$ & 0,5 & 8,9 & 0,3 & $-0,3$ & 0,0 & 0,3 & $-0,3$ & 0,0 & $-0,3$ & 0,0 & 0,3 \\
\hline 5 & G5 & $-11,6$ & 12,5 & $-0,9$ & 0,1 & $-1,0$ & 0,9 & 0,1 & $-1,0$ & 0,9 & $-0,5$ & 0,4 & 0,1 \\
\hline 6 & G6 & $-14,7$ & 2,7 & 12,0 & $-0,2$ & 0,8 & $-0,5$ & $-0,2$ & 0,8 & $-0,5$ & $-0,5$ & 0,0 & 0,5 \\
\hline 7 & G7 & $-7,9$ & $-12,1$ & $20,0^{*}$ & $-0,1$ & $-1,1$ & $1,2^{*}$ & $-0,1$ & $-1,1$ & $1,2^{*}$ & $-0,5$ & $-0,4$ & 0,8 \\
\hline 8 & G8 & 7,4 & $-6,4$ & $-1,0$ & 0,7 & $-2,0^{* *}$ & 1,3 & 0,7 & $-2,0 * *$ & 1,3 & 0,1 & $-0,4$ & 0,2 \\
\hline 9 & G9 & 3,9 & $-3,4$ & $-0,5$ & $-0,3$ & $-1,0$ & 1,4 & $-0,3$ & $-1,0$ & 1,4 & 0,0 & 0,0 & 0,0 \\
\hline 10 & G10 & 1,6 & $-2,2$ & 0,6 & 0,3 & $-1,1$ & 0,8 & 0,3 & $-1,1$ & 0,8 & 0,1 & $-0,4$ & 0,3 \\
\hline 11 & G11 & $16,8^{*}$ & $-7,9$ & $-8,9$ & 0,3 & $-0,6$ & 0,3 & 0,3 & $-0,6$ & 0,3 & $0,8^{*}$ & $-0,3$ & $-0,5$ \\
\hline 12 & G12 & $-10,7$ & $-1,9$ & 12,5 & 0,7 & $-1,0$ & 0,4 & 0,7 & $-1,0$ & 0,4 & $-0,3$ & $-0,1$ & 0,5 \\
\hline 13 & G13 & $-4,8$ & 0,6 & 4,2 & $-0,5$ & 0,7 & $-0,2$ & $-0,5$ & 0,7 & $-0,2$ & $-0,1$ & 0,1 & 0,1 \\
\hline 14 & G14 & 6,4 & 5,8 & $-12,2$ & $-0,5$ & 0,2 & 0,3 & $-0,5$ & 0,2 & 0,3 & 0,1 & 0,2 & $-0,3$ \\
\hline 15 & G15 & $21,7^{* *}$ & $-2,0$ & $-19,7^{*}$ & $-1,1$ & 0,9 & 0,2 & $-1,1$ & 0,9 & 0,2 & $0,7 *$ & $-0,1$ & $-0,6$ \\
\hline 16 & G16 & 2,5 & 3,3 & $-5,9$ & $-1,0$ & 1,0 & 0,0 & $-1,0$ & 1,0 & 0,0 & 0,1 & 0,1 & $-0,2$ \\
\hline 17 & G17 & 2,1 & 6,8 & $-8,9$ & $-0,8$ & $-0,1$ & 0,9 & $-0,8$ & $-0,1$ & 0,9 & 0,0 & 0,3 & $-0,3$ \\
\hline 18 & G18 & $-10,5$ & 3,7 & 6,8 & $-1,0$ & $-0,2$ & 1,1 & $-1,0$ & $-0,2$ & 1,1 & $-0,3$ & 0,2 & 0,1 \\
\hline 19 & G19 & $-2,3$ & $-5,2$ & 7,6 & $-0,4$ & 0,3 & 0,2 & $-0,4$ & 0,3 & 0,2 & $-0,1$ & $-0,2$ & 0,2 \\
\hline 20 & G20 & 4,9 & 3,2 & $-8,1$ & 0,9 & $-0,4$ & $-0,5$ & 0,9 & $-0,4$ & $-0,5$ & 0,1 & 0,1 & $-0,2$ \\
\hline 21 & G21 & $-4,9$ & 2,0 & 2,9 & $-0,7$ & 0,1 & 0,6 & $-0,7$ & 0,1 & 0,6 & $-0,1$ & 0,0 & 0,1 \\
\hline 22 & $\mathrm{G} 22$ & $-3,5$ & 3,7 & $-0,3$ & $-0,7$ & $1,5^{*}$ & $-0,8$ & $-0,7$ & $1,5^{*}$ & $-0,8$ & $-0,1$ & 0,1 & $-0,1$ \\
\hline 23 & G23 & $-7,9$ & 2,8 & 5,1 & 0,0 & 0,7 & $-0,7$ & 0,0 & 0,7 & $-0,7$ & $-0,2$ & 0,0 & 0,1 \\
\hline 24 & G24 & $-1,1$ & 4,8 & $-3,7$ & 0,0 & $-0,1$ & 0,1 & 0,0 & $-0,1$ & 0,1 & $-0,2$ & 0,5 & $-0,3$ \\
\hline 25 & G25 & $-3,1$ & $-2,1$ & 5,3 & 0,0 & 0,9 & $-0,9$ & 0,0 & 0,9 & $-0,9$ & $-0,2$ & $-0,1$ & 0,3 \\
\hline 26 & G26 & $-3,9$ & $-1,9$ & 5,8 & 0,6 & $-0,1$ & $-0,5$ & 0,6 & $-0,1$ & $-0,5$ & $-0,1$ & 0,0 & 0,1 \\
\hline 27 & $\mathrm{G} 27$ & $-3,1$ & 3,4 & $-0,3$ & 0,0 & 1,0 & $-1,1$ & 0,0 & 1,0 & $-1,1$ & $-0,1$ & 0,2 & $-0,1$ \\
\hline 28 & G28 & 6,4 & $-8,3$ & 1,9 & 0,2 & 1,1 & $-1,3$ & 0,2 & 1,1 & $-1,3$ & 0,1 & $-0,2$ & 0,1 \\
\hline 29 & G30 & $-0,1$ & 3,2 & $-3,2$ & 0,8 & $-0,7$ & $-0,1$ & 0,8 & $-0,7$ & $-0,1$ & $-0,1$ & 0,3 & $-0,2$ \\
\hline 30 & G32 & $-2,8$ & $-4,2$ & 7,0 & $2,1^{*}$ & $-0,6$ & $-1,4$ & $2,1 *$ & $-0,6$ & $-1,4$ & $-0,2$ & $-0,1$ & 0,3 \\
\hline 31 & G33 & 2,3 & $-1,2$ & $-1,2$ & $-0,2$ & 0,8 & $-0,6$ & $-0,2$ & 0,8 & $-0,6$ & 0,0 & 0,1 & $-0,1$ \\
\hline 32 & G34 & 2,5 & $-1,0$ & $-1,5$ & 0,2 & 0,1 & $-0,3$ & 0,2 & 0,1 & $-0,3$ & 0,0 & 0,0 & 0,0 \\
\hline 33 & G35 & $27,8^{* *}$ & $-12,2$ & $-15,5^{*}$ & 0,0 & 0,6 & $-0,6$ & 0,0 & 0,6 & $-0,6$ & $1,4 * *$ & $-0,6^{*}$ & $\begin{array}{l}* \\
*\end{array}$ \\
\hline
\end{tabular}

Keterangan: $* *$ nyata pada tingkat probabilitas $<0,01$ dan * nyata pada tingkat probabilitas $<0,05$. 
Hal tersebut menunjukkan bahwa produktivitas yang tinggi tidak hanya dipengaruhi tingkat prolifikasi yang tinggi saja tetapi juga didukung dengan beberapa karakter komponen hasil seperti panjang dan diameter tongkol yang besar. Analisis uji LSD 5\% menunjukkan bahwa dari 99 hibrida uji hanya 33 hibrida yang memiliki tingkat persentase tanaman prolifik berkisar 3,3-54,8\% yang berbeda nyata dengan varietas $P 27$ dengan persentase prolifik 0\% (Tabel 6).

Tabel 6. Ringkasan beberapa Jagung hibrida yang memiliki persentase tanaman prolifik, akumulasi hasil, hasil biji tongkol kesatu dan kedua, rasio hasil biji tongkol kesatu dan kedua

\begin{tabular}{|c|c|c|c|c|c|c|}
\hline \multirow[b]{2}{*}{ No } & \multirow[b]{2}{*}{ Hibrida } & \multirow{2}{*}{$\begin{array}{c}\text { Persentase } \\
\text { tanaman prolifik } \\
(\%) \\
(\%)\end{array}$} & \multirow[b]{2}{*}{$\begin{array}{l}\text { Akumulasi hasil tongkol } \\
\text { ke-1 dan ke-2 } \\
\text { (t ha-1) }\end{array}$} & \multicolumn{2}{|c|}{ Hasil biji (t ha-1) pada } & \multirow[b]{2}{*}{$\begin{array}{l}\text { Rasio } \\
\text { T2/T1 }\end{array}$} \\
\hline & & & & $\begin{array}{l}\text { Tongkol } \\
\text { ke-1 (T1) }\end{array}$ & $\begin{array}{l}\text { Tongkol } \\
\text { ke-2 (T2) }\end{array}$ & \\
\hline 1 & G7/Mal03 & $53,9 \mathrm{c}$ & $12,9 a b c$ & $10,8 \mathrm{~b}$ & $2,1 \mathrm{ac}$ & 0,19 \\
\hline 2 & G32/G102612 & 3,3 & $12,8 \mathrm{abc}$ & $12,7 \mathrm{abc}$ & 0,1 & 0,01 \\
\hline 3 & G1/G102612 & $26,1 \mathrm{c}$ & 10,9 & $9,8 \mathrm{~b}$ & $1,1 \mathrm{c}$ & 0,11 \\
\hline 4 & G8/Mal03 & $23,4 \mathrm{c}$ & 10,7 & $9,8 \mathrm{~b}$ & $0,9 \mathrm{c}$ & 0,10 \\
\hline 5 & G35/G102612 & $54,8 \mathrm{c}$ & 10,6 & 8,3 & 2,3 ac & 0,28 \\
\hline 6 & G4/Mal03 & $20,2 c$ & 10,4 & $9,8 \mathrm{~b}$ & 0,6 & 0,06 \\
\hline 7 & G16/CY6 & $17,8 \mathrm{c}$ & 10,2 & $9,7 \mathrm{~b}$ & 0,5 & 0,05 \\
\hline 8 & G11/G102612 & $48,7 \mathrm{c}$ & 9,8 & 8,0 & $1,8 \mathrm{c}$ & 0,23 \\
\hline 9 & G12/Mal03 & $26,5 \mathrm{c}$ & 9,8 & $8,9 b$ & $0,9 \mathrm{c}$ & 0,10 \\
\hline 10 & G20/CY6 & $20,3 c$ & 9,8 & $9,3 \mathrm{~b}$ & 0,4 & 0,04 \\
\hline 11 & G7/G102612 & $32,8 \mathrm{c}$ & 9,7 & $8,7 \mathrm{~b}$ & $0,9 \mathrm{c}$ & 0,10 \\
\hline 12 & G15/CY6 & $30,0 \mathrm{c}$ & 9,6 & $8,8 \mathrm{~b}$ & $0,8 \mathrm{c}$ & 0,09 \\
\hline 13 & G24/CY6 & $20,8 c$ & 9,6 & $8,6 \mathrm{~b}$ & $1,1 \mathrm{c}$ & 0,12 \\
\hline 14 & G10/Mal03 & $22,1 \mathrm{c}$ & 9,6 & $8,7 \mathrm{~b}$ & $0,9 \mathrm{c}$ & 0,10 \\
\hline 15 & G8/G102612 & $38,6 \mathrm{c}$ & 9,4 & 8,4 & $1,0 \mathrm{c}$ & 0,12 \\
\hline 16 & G6/CY6 & $22,9 c$ & 9,1 & 8,5 & 0,6 & 0,07 \\
\hline 17 & G1/CY6 & $24,3 \mathrm{c}$ & 9,1 & $8,6 \mathrm{~b}$ & 0,5 & 0,06 \\
\hline 18 & G6/Mal03 & $26,6 \mathrm{c}$ & 9,0 & 7,9 & $1,1 \mathrm{c}$ & 0,14 \\
\hline 19 & G28/G102612 & $19,0 \mathrm{c}$ & 8,8 & 8,4 & 0,4 & 0,05 \\
\hline 20 & G2/CY6 & $24,1 \mathrm{c}$ & 8,7 & 8,0 & 0,6 & 0,08 \\
\hline 21 & G7/CY6 & $27,4 \mathrm{c}$ & 8,6 & 7,7 & $0,9 \mathrm{c}$ & 0,11 \\
\hline 22 & G15/G102612 & $54,7 c$ & 8,5 & 6,8 & $1,7 \mathrm{c}$ & 0,25 \\
\hline 23 & G14/CY6 & $32,8 \mathrm{c}$ & 8,5 & 7,6 & $0,9 \mathrm{c}$ & 0,12 \\
\hline 24 & G10/G102612 & $29,9 c$ & 8,3 & 7,4 & $0,9 \mathrm{c}$ & 0,12 \\
\hline 25 & G16/G102612 & $18,1 \mathrm{c}$ & 8,3 & 7,7 & 0,6 & 0,08 \\
\hline 26 & G17/CY6 & $28,7 c$ & 7,8 & 7,1 & $0,7 \mathrm{c}$ & 0,10 \\
\hline 27 & G14/G102612 & $34,4 \mathrm{c}$ & 7,8 & 6,9 & $0,9 \mathrm{c}$ & 0,13 \\
\hline 28 & G5/CY6 & $31,7 c$ & 7,7 & 6,9 & $0,9 \mathrm{c}$ & 0,13 \\
\hline 29 & G11/CY6 & $22,9 c$ & 7,7 & 7,1 & 0,6 & 0,08 \\
\hline 30 & G12/CY6 & $17,7 \mathrm{c}$ & 7,1 & 6,8 & 0,4 & 0,05 \\
\hline 31 & G17/G102612 & $25,1 \mathrm{c}$ & 7,0 & 6,4 & 0,6 & 0,09 \\
\hline 32 & G10/CY6 & $25,0 \mathrm{c}$ & 6,3 & 6,0 & 0,2 & 0,04 \\
\hline 33 & G8/CY6 & $23,6 \mathrm{c}$ & 6,2 & 5,8 & 0,4 & 0,07 \\
\hline & NASA 29 (a) & 37,5 & 11,3 & 9,9 & 1,3 & \\
\hline & Bisi 2 (b) & 70,2 & 9,8 & 7,2 & 2,6 & \\
\hline & P27 (c) & 0,0 & 10,3 & 10,3 & 0,0 & \\
\hline & Rata-rata & 19,7 & 9,5 & 8,9 & 0,6 & \\
\hline & LSD & 17,7 & 1,5 & 1,3 & 0,7 & \\
\hline & KK & 21,4 & 10,5 & 9,2 & 29,2 & \\
\hline
\end{tabular}

Keterangan: Angka pada kolom yang sama diikuti oleh huruf a = menunjukkan nyata lebih tinggi dibanding Nasa $29, \mathrm{~b}=$ nyata lebih tinggi dibanding Bisi 2 , dan c = nyata lebih tinggi dibanding P 27 berdasarkan uji LSD $5 \%$

Namun hibrida yang memiliki persentase tanaman prolifik tinggi tidak selalu memiliki hasil biji yang tinggi. Hal tersebut dapat ditunjukkan pada varietas Bisi 2 yang 
memiliki tingkat persentase tanaman prolifik paling tinggi yaitu $70,2 \%$ namun hasil biji yang diperoleh 9,8 t ha $^{-1}$ nyata lebih rendah dibanding hibrida G32/G102612 yang memiliki persentase tanaman prolifik yang rendah yaitu 3,3\% namun memiliki hasil biji yang tinggi yaitu $12,8 \mathrm{t} \mathrm{ha}^{-1} \mathrm{Hal}$ tersebut menunjukkan bahwa tingkat prolifikasi yang tinggi tidak selalu mendukung produktivitas yang tinggi, sehingga dalam perakitan varietas jagung hibrida dengan prolifikasi yang tinggi juga harus didukung dengan karakter lainnya seperti ukuran tongkol yang besar. Analisis korelasi menunjukkan bahwa variabel panjang dan diameter tongkol berkorelasi positif nyata dengan hasil biji dengan nilai koefisien korelasi ( $r$ ) berkisar 0,39-0,48. (Tabel 7) Korelasi tersebut menggambarkan bahwa semakin besar ukuran tongkol maka semakin besar hasil yang diperoleh.

Tabel 7. Korelasi antar variabel persentase prolifik, hasil dan komponen hasil

\begin{tabular}{|c|c|c|c|c|c|c|c|c|c|c|}
\hline Variabel & $\begin{array}{l}\text { Total } \\
\text { hasil }\end{array}$ & $\mathrm{H} 1$ & $\mathrm{H} 2$ & $\begin{array}{l}\text { Ratio } \\
\mathrm{H} 2 / \mathrm{H} 1\end{array}$ & DT1 & DT2 & $\begin{array}{l}\text { Ratio } \\
\text { DT2/DT1 }\end{array}$ & PT 1 & PT 2 & Ratio PT2/PT1 \\
\hline $\begin{array}{l}\text { Persentase } \\
\text { prolifik }\end{array}$ & 0.18 & $-0.22 *$ & $0.95^{* *}$ & $0.96^{* *}$ & $-0.36 * *$ & $0.52 * *$ & $0.55^{* *}$ & 0.13 & $0.57 * *$ & $0.57 * *$ \\
\hline $\begin{array}{l}\text { Total hasil } \\
(\mathrm{H} 1+\mathrm{H} 2)\end{array}$ & & $0.91 * *$ & $0.3^{*}$ & 0.18 & $0.52 * *$ & 0.09 & 0.04 & $0.22 *$ & -0.07 & -0.1 \\
\hline $\begin{array}{l}\text { Hasil Tongkol } \\
\text { ke-1 (H1) }\end{array}$ & & & -0.11 & $-0.24 *$ & $0.66 * *$ & -0.09 & -0.16 & 0.2 & $-0.27 *$ & $-0.3^{* *}$ \\
\hline $\begin{array}{l}\text { Hasil Tongkol } \\
\text { ke-2 }(\mathrm{H} 2)\end{array}$ & & & & $0.98^{* *}$ & $-0.28^{*}$ & $0.44 * *$ & $0.46 * *$ & 0.06 & $0.47 * *$ & $0.47 * *$ \\
\hline $\begin{array}{l}\text { RatioH2/H1 } \\
\text { Diamter }\end{array}$ & & & & & $-0.34^{* *}$ & $0.42 * *$ & $0.45^{* *}$ & 0.03 & $0.48 * *$ & $0.48^{* *}$ \\
\hline $\begin{array}{l}\text { Tongkol ke-1 } \\
\text { (DT1) } \\
\text { Diamter }\end{array}$ & & & & & & $-0.22 *$ & $-0.31 * *$ & 0.06 & $-0.31 * *$ & $-0.32 * *$ \\
\hline $\begin{array}{l}\text { Tongkol ke-2 } \\
\text { (DT2) }\end{array}$ & & & & & & & $0.99 * *$ & $0.26^{*}$ & $0.87 * *$ & $0.87 * *$ \\
\hline Ratio DT2/DT1 & & & & & & & & $0.25 *$ & $0.88 * *$ & $0.88 * *$ \\
\hline $\begin{array}{l}\text { Panjang } \\
\text { Tongkol ke-1 } \\
\text { (PT 1) } \\
\text { Panjang }\end{array}$ & & & & & & & & & $0.31 * *$ & 0.18 \\
\hline $\begin{array}{l}\text { Tongkol ke-2 } \\
\text { (PT 2) }\end{array}$ & & & & & & & & & & $0.99 * *$ \\
\hline
\end{tabular}

Sejalan dengan beberapa hasil penelitian juga menyatakan bahwa terdapat korelasi positif antara panjang tongkol dan diameter tongkol terhadap hasil (Mousavi \& Nagy, 2021; Tucker et al., 2020). Hal ini menunjukkan bahwa jagung hibrida yang memiliki tingkat prolifikasi namun tidak diiringi dengan ukuran tongkol yang besar belum meningkatkan hasil persatuan luas. Sehingga disarankan untuk meningkatkan produktifitas jagung selain melaui perakitan varietas dengan prolifikasi tinggi juga harus diikuti dengan ukuran dan bobot tongkol yang besar baik tongkol pertama maupun kedua. 
Tabel 8. Ringkasan beberapa jagung hibrida yang memiliki diameter tongkol, rasio diameter tongkol, panjang tongkol, rasio panjang tongkol ke-1 dan tongkol ke-2

\begin{tabular}{|c|c|c|c|c|c|c|c|}
\hline No & Hibrida & $\begin{array}{l}\text { Diameter } \\
\text { Tongkol } \\
\text { ke-1 (DT1) } \\
(\mathrm{cm})\end{array}$ & $\begin{array}{l}\text { Diameter } \\
\text { Tongkol } \\
\text { ke-2 (DT2) } \\
(\mathrm{cm})\end{array}$ & $\begin{array}{c}\text { Rasio } \\
\text { DT1/DT2 }\end{array}$ & $\begin{array}{l}\text { Panjang } \\
\text { Tongkol } \\
\text { ke-1 } \\
\text { (PTK1) } \\
\text { (cm) }\end{array}$ & $\begin{array}{l}\text { Panjang } \\
\text { Tongkol } \\
\text { ke-2 } \\
\text { (PTK1) } \\
(\mathrm{cm})\end{array}$ & $\begin{array}{c}\text { Rasio PT1/ } \\
\text { PT2 }\end{array}$ \\
\hline 1 & G7/Mal03 & 4,5 & $4,0 \mathrm{c}$ & 0,9 & 18,1 & $11,4 \mathrm{c}$ & 0,6 \\
\hline 2 & G32/G102612 & $4,8 a b$ & 1,3 & 0,3 & $18,6 \mathrm{~b}$ & 2,4 & 0,1 \\
\hline 3 & G1/G102612 & 4,6 & $3,9 \mathrm{c}$ & 0,9 & 17,3 & $11,6 \mathrm{c}$ & 0,7 \\
\hline 4 & G8/Mal03 & 4,5 & $4,1 \mathrm{c}$ & 0,9 & 17,8 & $12,3 \mathrm{c}$ & 0,7 \\
\hline 5 & G35/G102612 & 4,4 & $2,7 c$ & 0,6 & 16,9 & $7,7 \mathrm{c}$ & 0,5 \\
\hline 6 & G4/Mal03 & 4,5 & $2,5 \mathrm{c}$ & 0,6 & 17,4 & 6,6 & 0,4 \\
\hline 7 & G16/CY6 & $4,8 \mathrm{~b}$ & $3,5 \mathrm{c}$ & 0,7 & 17,3 & $8,3 \mathrm{c}$ & 0,5 \\
\hline 8 & G11/G102612 & 4,4 & $2,8 \mathrm{c}$ & 0,6 & 17,3 & $8,6 \mathrm{c}$ & 0,5 \\
\hline 9 & G12/Mal03 & $4,7 \mathrm{~b}$ & $3,9 \mathrm{c}$ & 0,8 & 17,6 & $11,1 \mathrm{c}$ & 0,6 \\
\hline 10 & G20/CY6 & 4,5 & $3,6 \mathrm{c}$ & 0,8 & 17,6 & $10,0 \mathrm{c}$ & 0,6 \\
\hline 11 & G7/G102612 & 4,4 & $3,6 \mathrm{c}$ & 0,8 & $18,9 \mathrm{~b} \mathrm{c}$ & $12,8 \mathrm{c}$ & 0,7 \\
\hline 12 & G15/CY6 & $4,7 \mathrm{~b}$ & $2,5 \mathrm{c}$ & 0,5 & 17,0 & 6,7 & 0,4 \\
\hline 13 & G24/CY6 & $4,6 \mathrm{~b}$ & $3,4 \mathrm{c}$ & 0,7 & 17,4 & $12,1 \mathrm{c}$ & 0,7 \\
\hline 14 & G10/Mal03 & 4,5 & $3,8 \mathrm{c}$ & 0,9 & 17,9 & $11,4 \mathrm{c}$ & 0,6 \\
\hline 15 & G8/G102612 & $4,6 \mathrm{~b}$ & $3,9 \mathrm{c}$ & 0,8 & $18,5 \mathrm{~b}$ & $12,8 \mathrm{c}$ & 0,7 \\
\hline 16 & G6/CY6 & 4,3 & $3,4 \mathrm{c}$ & 0,8 & $18,5 \mathrm{~b}$ & $11,9 \mathrm{c}$ & 0,6 \\
\hline 17 & G1/CY6 & 4,4 & $3,5 \mathrm{c}$ & 0,8 & 18,3 & $10,5 \mathrm{c}$ & 0,6 \\
\hline 18 & G6/Mal03 & 4,2 & $2,4 \mathrm{c}$ & 0,6 & 17,5 & 4,2 & 0,2 \\
\hline 19 & G28/G102612 & 4,5 & $3,7 c$ & 0,8 & $18,6 \mathrm{~b}$ & $8,7 \mathrm{c}$ & 0,5 \\
\hline 20 & $\mathrm{G} 2 / \mathrm{CY} 6$ & 4,4 & $3,8 \mathrm{c}$ & 0,9 & 17,8 & $12,5 \mathrm{c}$ & 0,7 \\
\hline 21 & G7/CY6 & 4,5 & $3,1 \mathrm{c}$ & 0,7 & 17,2 & $12,8 \mathrm{c}$ & 0,7 \\
\hline 22 & G15/G102612 & 4,4 & $4,0 \mathrm{c}$ & 0,9 & 17,6 & $13,3 \mathrm{c}$ & 0,8 \\
\hline 23 & G14/CY6 & 4,4 & $2,7 \mathrm{c}$ & 0,6 & 16,2 & $7,9 \mathrm{c}$ & 0,5 \\
\hline 24 & G10/G102612 & 4,4 & $3,5 \mathrm{c}$ & 0,8 & $19,5 \mathrm{~b} \mathrm{c}$ & $13,7 \mathrm{c}$ & 0,7 \\
\hline 25 & G16/G102612 & 4,4 & $3,6 \mathrm{c}$ & 0,8 & 17,4 & $10,7 c$ & 0,6 \\
\hline 26 & G17/CY6 & 4,5 & $3,9 \mathrm{c}$ & 0,9 & $18,5 \mathrm{~b}$ & $12,1 \mathrm{c}$ & 0,7 \\
\hline 27 & G14/G102612 & 4,3 & $3,8 \mathrm{c}$ & 0,9 & 17,5 & $12,1 \mathrm{c}$ & 0,7 \\
\hline 28 & G5/CY6 & 4,3 & $3,4 c$ & 0,8 & 17,5 & $12,7 \mathrm{c}$ & 0,7 \\
\hline 29 & G11/CY6 & 4,3 & $2,5 \mathrm{c}$ & 0,6 & 18,2 & $9,1 \mathrm{c}$ & 0,5 \\
\hline 30 & G12/CY6 & 4,5 & $3,6 \mathrm{c}$ & 0,8 & 17,4 & $9,6 \mathrm{c}$ & 0,6 \\
\hline 31 & G17/G102612 & 4,2 & $3,6 \mathrm{c}$ & 0,8 & 17,9 & $11,8 \mathrm{c}$ & 0,7 \\
\hline 32 & G10/CY6 & 4,2 & $3,4 \mathrm{c}$ & 0,8 & 16,6 & $12,2 \mathrm{c}$ & 0,7 \\
\hline \multirow[t]{7}{*}{33} & G8/CY6 & 4,2 & $3,2 \mathrm{c}$ & 0,8 & 17,2 & $14,3 \mathrm{c}$ & 0,8 \\
\hline & NASA 29 (a) & 4,6 & 3,8 & 0,8 & 19,3 & 11,4 & 0,6 \\
\hline & Bisi 2 (b) & 4,4 & 4,1 & 0,9 & 16,9 & 13,4 & 0,8 \\
\hline & $\mathrm{P} 27$ (c) & 5,1 & 0,0 & 0,0 & 17,5 & 0,0 & 0,0 \\
\hline & Rata-rata & 4,5 & 2,9 & & 17,6 & 8,5 & \\
\hline & LSD & 2,0 & 2,3 & & 1,4 & 6,9 & \\
\hline & KK & 2,7 & 19,2 & & 4,9 & 50,7 & \\
\hline
\end{tabular}

Keterangan: Angka pada kolom yang sama diikuti oleh huruf a = menunjukkan nyata lebih tinggi dibanding Nasa 29, $\mathrm{b}=$ nyata lebih tinggi dibanding Bisi 2, dan c = nyata lebih tinggi dibanding P 27 berdasarkan uji LSD 5\%.

Rasio ukuran panjang dan diameter tongkol ke-1 dan ke-2 merupakan gambaran keseragaman ukuran tongkol ke-1 dan ke-2,
Nilai ratio mendekati 1 menunjukkan semakin seragam ukuran pada tongkol ke-1 dan tongkol ke-2. Genotipe jagung prolifik 
yang ideal sebaiknya memiliki ukuran tongkol yang sama antara tongkol ke-1 dan Ke-2. Namun sejumlah hibrida uji yang memiliki memiliki potensi genetik prolifik tidak memiliki ukuran tongkol ke-1 dan ke-2 yang sama, bahkan banyak tongkol ke-2 yang tidak menghasilkan biji (baren). Hibrida G7/Mal03, G35/G102612, G15/ G102612 dan Bisi 2 yang memiliki persentase tanaman prolifik $>50 \%$ menunjukkan tingkat keseragaman ukuran tongkol ke-1 dan ke-2 yang beragam. Keseragaman ukuran tongkol ke-1 dan tongkol ke-2 yang paling baik ditunjukkan oleh varietas Bisi 2. Rasio ukuran panjang tongkol pertama dengan kedua yaitu 0,7 dan rasio diameter tongkol pertama dan kedua sebesar 0,9. Sedangkan hibrida G7/Mal03, G35/G102612, G15/ G102612 memiliki ratio ukuran diameter tongkol ke1 dan ke-2 berkisar 0,6-0,9 dan ratio ukuran panjang tongkol ke-1 dan ke-2 berkisar 0,40,6 . Hal tersebut menunjukkan bahwa perlu perbaikan tingkat prolifikasi dan keseragaman ukuran tongkol pertama dan kedua pada galur-galur yang tersedia dalam perakitan varietas jagung hibrida prolifik (Tabel 8). Hasil analisis korelasi pada Tabel 7 menunjukkan bahwa total hasil biji yang tinggi tidak berkorelasi nyata dengan persentase prolifik $(r=0,18)$, namun berkorelasi nyata dengan hasil biji dari tongkol pertama $(r=0,91)$, meskipun secara keseluruhan korelasi persentase prolifik terhadap hasil tidak nyata tidak berarti hasil biji pada tongkol kedua tidak berpengaruh terhadap hasil biji total. hasil biji dari tongkol pertama memiliki korelasi yang rendah terhadap hasil biji total $(r=0,30)$. Hal ini menunjukkan bahwa produktivitas yang tinggi lebih ditentukan oleh besarnya hasil biji dari tongkol pertama, sedangkan persentase prolifik yang tinggi belum dapat meningkatkan produktifitas. Hal tersebut dapat dilihat dari perbandingan hasil biji dari varietas Bisi 2 yang memiliki persentase prolifik yang tinggi yaitu $70,2 \%$ dengan hibrida G32/G1022612 yang memiliki persentase tanaman prolifik yang rendah yaitu hanya $3,3 \%$. Hasil biji dari varietas Bisi 2 hanya 9,8 $\mathrm{t} \mathrm{ha}^{-1}$ nyata lebih rendah dibanding hibrida G32/G1022612 dengan hasil biji 12,8 $\mathrm{t} \mathrm{ha}^{-1}$ (Tabel 6).

Perbedaan hasil yang nyata dari hibrida tersebut sangat dipengaruhi oleh hasil biji dari tongkol pertama. Hasil biji dari tongkol pertama varietas Bisi 2 hanya 7,2 $\mathrm{t} \mathrm{ha}^{-1}$ nyata lebih rendah dibanding hibrida G32/G1022612 dengan hasil biji dari tongkol pertama sebesar $12,7 \mathrm{t} \mathrm{ha}^{-1}$. Penambahan hasil biji dari tongkol kedua pada varietas Bisi 2 hanya sebesar $2,7 \mathrm{t} \mathrm{ha}^{-1}$ sehingga akumulasi hasil biji dari tongkol pertama dan kedua hanya 9,8 $\mathrm{t} \mathrm{ha}^{-1}$ masih lebih rendah dibanding hibrida G32/G1022612 dengan hasil biji 12,8 $\mathrm{t} \mathrm{ha}^{-1}$ (Tabel 6).

Nilai ragam DGU lebih kecil dibandingkan nilai ragam DGK pada semua parameter kecuali panjang tongkol 2. Hal tersebut menunjukkan bahwa hampir seluruh parameter oleh aksi gen non aditif Hasil ini diperkuat oleh nilai varian dominan yang lebih besar dibandingkan varian aditif pada hampir semua parameter yang diamati (Tabel 9). Hasil ini senada dengan penelitian Ahmed et al. (2015) dan Chandel \& Mankotia (2014) yang menunjukkan bahwa variabel hasil biji dan diameter tongkol dipengaruhi oleh gen non aditif. Namun hal berbeda dikemukakan oleh Bisht \& Mani (2016) dalam penelitiannya yang menunjukkan bahwa prolifikasi, diameter tongkol, dan total hasil lebih dipengaruhi oleh gen aditif. 
Nilai heritabilitas arti sempit yang ditunjukkan parameter tersebut adalah rendah sampai sedang. Semua parameter yang diamati menunjukkan nilai heritabilitas rendah kecuali diameter tongkol 1 dengan nilai heritabilitas sedang. Heritabilitas arti sempit menunjukkan pengaruh gen aditif terhadap penampilan suatu karakter. Ketika nilai heritabilitas rendah berarti gen non aditif lebih berperan dalam penampilan karakter tersebut. Seleksi karakter yang dipengaruhi gen non aditif dilakukan pada generasi lanjut (Hallauer et al., 2010). Perbaikan karakter dengan heritabilitas rendah dilakukan melakukan seleksi antar rekombinan dalam populasi segregasi (Carvalho et al., 2017).

Tabel 9. Parameter genetik variabel persentase tanaman prolifik, hasil biji, panjang tongkol dan diameter tongkol

\begin{tabular}{lrrrrrrr}
\multicolumn{1}{c}{ Variabel } & $\sigma^{2}$ DGU & $\sigma^{2}$ DGK & \multicolumn{1}{c}{$\sigma^{2} \mathrm{~A}$} & \multicolumn{1}{c}{$\sigma^{2} \mathrm{D}$} & \multicolumn{1}{c}{$\sigma^{2} \varepsilon$} & $\mathrm{h}_{\mathrm{b}}^{2}$ & $\mathrm{~h}_{\mathrm{ns}}^{2}$ \\
& & & & & & & \\
\hline Persentase tongkol ke-2 & 34,678 & 213,146 & 138,710 & 213,146 & 350,119 & 0,501 & 0,198 \\
Total Hasil & 0,216 & 3,084 & 0,864 & 3,084 & 2,612 & 0,602 & 0,132 \\
Hasil biji tongkol ke-1 & 0,272 & 2,579 & 1,088 & 2,579 & 1,856 & 0,664 & 0,197 \\
Hasil biji tongkol ke-2 & 0,023 & 0,382 & 0,094 & 0,382 & 0,488 & 0,494 & 0,097 \\
Diameter tongkol ke-1 & 0,795 & 4,517 & 3,180 & 4,517 & 4,347 & 0,639 & 0,264 \\
Diameter tongkol ke-2 & 9,291 & 42,903 & 37,164 & 42,903 & 601,700 & 0,117 & 0,055 \\
Panjang tongkol ke-1 & 0,162 & 0,780 & 0,649 & 0,780 & 2,217 & 0,392 & 0,178 \\
Panjang tongkol ke-2 & 2,256 & 1,731 & 9,025 & 1,731 & 56,522 & 0,160 & 0,134
\end{tabular}

Keterangan: $\sigma^{2} \mathrm{DGU}=$ ragam DGU, $\sigma^{2} \mathrm{DGK}=$ ragam $\mathrm{DGK}, \sigma^{2} \mathrm{~A}=$ ragam aditif, $\sigma^{2} \mathrm{D}=$ ragam dominan, $\sigma^{2} \varepsilon=$ ragam lingkungan, $\mathrm{h}_{\mathrm{b}}^{2}=$ heritabilitas arti luas, $\mathrm{h}_{\mathrm{ns}}^{2}=$ heritabilitas arti sempit

\section{SIMPULAN}

1. Galur G7 memiliki nilai daya gabung umum baik untuk karakter persentase tanaman prolifik.

2. Hibrida G35/G102612 merupakan hibrida uji dengan persentase tanaman prolifik tertinggi $55,8 \%$ dan Hibrida G7/Mal03 dengan hasil biji 12,9 $\mathrm{t} \mathrm{ha}^{-1}$ persentase tanaman prolifik $53,9 \%$ merupakan hibrida prolifik dengan hasil tinggi

3. Aksi gen non aditif lebih berperan dalam penampilan karakter hasil pada jagung prolifik.

\section{DAFTAR PUSTAKA}

Adebayo, M. A., \& Menkir, A. (2015). Assessment of hybrids of drought tolerant maize (Zea mays L.) inbred lines for grain yield and other traits under stress managed conditions. Nigerian Journal of Genetics, 28(2), 19-23. https://doi.org/10.1016/j.nigjg.2015.06. 004

Ahmed, A., Amiruzzaman, M., Begum, S., Alam, M. K., \& Rohman, M. M. (2015). Analysis of combining ability and gene action of field corn through line $x$ tester method. J Expt. Biosci., 6(2), 6i-66. 
Al-Naggar, A. M. M., Shabana, R., \& Rabie, A. M. (2012). Inheritance of Maize Prolificacy under High Plant Density. Egyptian Journal of Plant Breeding, 16(2),1-27. https://doi.org/10.12816/0003929

Azrai, M., \& Mejaya, M. J. (2014). Daya gabung galur-galur jagung berkualitas protein tinggi. Penelitian Pertanian Tanaman Pangan, 33(3), 137-147.

Bisht, G. S., \& Mani, V. P. (2016). A study of prolificacy through mass selection in maize for Northern-Western Himalayas. Journal of Biotechnology and Crop Science, 5(7), 92-95.

Carvalho, I. R., Nardino, M., Demari, G. H., de Pelegrin, A. J., Ferrari, M., Szareski, V. J., de Oliveira, V. F., Barbosa, M. H., de Souza, V. Q., \& de Oliveira, A. C. (2017). Components of variance and interrelation of important traits for maize (Zea mays) breeding. Australian Journal of Crop Science, 11(8), 982.

Chandel, U., \& Mankotia, B. S. (2014). Combining ability in local and CIMMYT inbred lines of maize (Zea mays L .) for grain yield and yield components using line $\times$ tester analysis. SABRAO Journal of Breeding \& Genetics, 46(2), 256-264.

Efendi, R., Baharuddin, Herawati, Andayani, N. N., Kalqutny, S. H., \& Azrai, M. (2020). Evaluation of prolific hybrids maize performance on different population densities and nitrogen level. IOP Conference Series: Earth and Environmental Science, 484, 012095. https://doi.org/10.1088/17551315/484/1/012095
Efendi, R., Makkulawu, A. T., \& Azrai, M. (2017). Daya gabung inbrida jagung toleran cekaman kekeringan dan nitrogen rendah pada pembentukan varietas hibrida. Penelitian Pertanian Tanaman Pangan, 1(2), 83-96.

Estakhr, A., \& Heidari, B. (2012). Combining ability and gene action for maturity and agronomic traits in different heterotic groups of maize inbred lines and their diallel crosses. Journal of Crop Science and Biotechnology, 15(3), 219-229. https://doi.org/10.1007/s12892-0120030-1

Fan, J. J., Wang, N. Z., Zhu, Y. S., Cui, Z. H., Yuan, Y. H., \& Zhang, L. J. (2012). Research progress on prolificacy in maize. J Maize Sci, 20(5), 143-146.

Freddy, I. M., Respatiadi, H., \& Gupta, G. E. . (2018). Mereformasi Kebijakan Perdagangan untuk Menurunkan Harga Jagung di Indonesia. Center for Indonesian Policy Studies (CIPS).

Hallauer, A. R. R., Carena, M. J., Filho, J. B. M., Miranda, J. B., Carena, M. J., Filho, J. B. M., \& Miranda, J. B. (2010). Quantitative Genetics in Maize (6th ed.). Springer Science \& Business Media. https://doi.org/10.1017/СBO978110741 5324.004

Harriman, J. C., \& Nwammadu, C. A. (2016). Utilization of diallel analyses for heritability, GCA and SCA studies in crop improvement. American Advances Journal of Biological Science, 2(5), 159167.

https://doi.org/10.18869/IJABBR.2016.1 0 
Hibbiny, Y. I. M. A. L., Mabrouk, A. H., \& Mahmoud, B. A. (2019). Line $x$ tester analysis for yield components and fiber properties in some cotton crosses of (Gossypium barbadense L.). Menoufia Journal of Plant Production, 4(6), 505525.

Kamara, M. M., El-Degwy, I. S., \& Koyama, H. (2014). Estimation combining ability of some maize inbred lines using line $x$ tester mating design under two nitrogen levels. Australian Journal of Crop Science, 8(9), 1336-1342.

Kementerian Pertanian. (2019). Direktori Perkembangan Konsumsi Pangan. In Badan Ketahan Pangan.

Kementerian Pertanian Republik Indonesia. (2018). Statistik Pertanian. Pusat Data dan Sistem Informasi Pertanian Kementerian Pertanian Republik Indonesia.

Khatefov, E. B., \& Appaev, S. P. (2019). Using genetic Potential of Teosinte from Collection of $\mathrm{NI}$ Vavilov Research Institute of Plant Industry to Expand Polymorphism of Prolific Maize (Zea mays L.). KnE Life Sciences, 992-1002.

Makkulawu, A. T., Isnaini, M., \& Muliadi, A. (2007). Combining ability of CIMMYT maize lines with two Indonesian tester parents. Jurnal Penelitian Pertanian Tanaman Pangan, 26(3), 161-166.

Melchinger, A. E. (2010). The international conference on "heterosis in plants." Theoretical and Applied Genetics, 120(2),201-203.

https://doi.org/10.1007/s00122-009-

1211-2
Meseka, S. K., Menkir, A., \& Ajala, S. (2011). Genetic analysis of performance of maize inbred lines under drought stress. Journal of Crop Improvement, 25(5), 521-539. https://doi.org/10.1080/15427528.201 1.592570

Meseka, S. K., Menkir, A., Olakojo, S., Jalloh, A., Coulibaly, N., \& Bossey, O. (2016). Yield stability of yellow maize hybrids in the savannas of West Africa. Agronomy Journal, 108(4), 1313-1320. https://doi.org/10.2134/agronj2015.03 66

Mousavi, S. M. N., \& Nagy, J. (2021). Evaluation of plant characteristics related to grain yield of FAO410 and FAO340 hybrids using regression models. Cereal Research Communications, 49(1), 161-169. https://doi.org/10.1007/s42976-02000076-3

Pelu, A., Tupan, J. M., \& Paillin, D. B. (2016). Optimasi penentuan campuran pakan ayam ras petelur dengan menggunakan metode goal programming pada peternakan bhumyamca unggas. Arika, 10(2),97-104.

https://ojs3.unpatti.ac.id/index.php/ari ka/article/view/433

Priyanto, S. B., Iriani, R. N., \& Makkulawu, A. T. (2016). Stabilitas Hasil Jagung Varietas Hibrida Harapan Umur Genjah Yield Stability Analysis of Promising Early Maturing Hybrid Maize. Penelitian Pertanian Tanaman Pangan, 35(2), 125132.

Pusdatin. (2018). Buletin Konsumsi Pangan (Vol. 9, Issue 1). Pusat Data dan Sistem 
Informasi Pertanian Sekretariat Jenderal Kementerian Pertanian.

Qosim, W. A. (2018). METODE PEMULIAAN TANAMAN (1st ed., Vol. 84). Plantaxia. http://ir.obihiro.ac.jp/dspace/handle/1 0322/3933

Rahaman, A. (2016). Study of nature and magnitude of gene action in hybrid rice (Oryza sativa L .) through experiment of line $x$ tester mating design. International Journal of Applied Research, 2(2), 405410.

Rameeh, V., \& Andarkhor, S. A. (2017). Line $x$ tester analysis for duration of flowering, yield components and seed yield in sunflower (Helianthus annuus L.). Helia, 40(66), 61-70.

Ross, F., Di Matteo, J., \& Cerrudo, A. (2020). Maize prolificacy: a source of reproductive plasticity that contributes to yield stability when plant population varies in drought-prone environments. Field Crops Research, 247, 107699.

Ruswandi, D., Supriatna, J., Makkulawu, A. T., Waluyo, B., Marta, H., Suryadi, E., \& Ruswandi, S. (2015). Determination of Combining Ability and Heterosis of Grain Yield Components for Maize Mutants Based on Line $x$ Tester Analysis. Asian Journal of Crop Science, 7(1), 19-33.

Setyowidianto, E. P., \& Basuki, N. (2017). Daya gabung dan heterosis galur jagung ( Zea mays L .) pada karakter hasil dan komponen hasil. J.Agron. Indonesia, 45(2), 124-129.

Sharma, J. R. (1988). Statistical and biometrical tehniques in plant breeding (1st ed.). New Age International Publisher.

Singh, R. K., \& Chaudhary, B. D. (1979). Biometrical methods in quantitative genetic analysis. Kalyani Publisher.

Stansfield, R. (1983). Genetika. Terjemahan oleh Mohidin A, Apandi, Lanny T. 1991. Erlangga.

Sujiprihati, S., Azrai, M., \& Yuliandry, A. (2006). Keragaan genotipe jagung bermutu protein tinggi (QPM) di dua tipologi lahan yang berbeda. Jurnal Agrotropika., XI(2), 90-100.

Sutoro, \& Setyowati, M. (2015). Daya Gabung Umum, Daya Gabung Khusus dan Keragaan Hasil Hibrida Jagung pada Dua Tingkat Pumupukan N. Jurnal Penelitian Pertanian Tanaman Pangan, 34(1),55-59.

https://doi.org/10.21082/jpptp.v34n1.2 015.p55-59

Tinca, E., Has, I., \& A, C. (2016). Prolificacy Study of Maize (Zea mays L.) Inbred Lines and Hybrids on ARDS-Turda Emilia. Bulletin UASVM Series Agriculture, 73(2),1843-5246. https://doi.org/10.15835/buasvmcn-agr

Tucker, S. L., Dohleman, F. G., Grapov, D., Flagel, L., Yang, S., Wegener, K. M., Kosola, K., Swarup, S., Rapp, R. A., Bedair, M., Halls, S. C., Glenn, K. C., Hall, M. A., Allen, E., \& Rice, E. A. (2020). Evaluating maize phenotypic variance, heritability, and yield relationships at multiple biological scales across agronomically relevant environments. Plant Cell and Environment, 43(4), 880902. https://doi.org/10.1111/pce.13681 
Tyagi, V., Dhillon, S. K., \& Kaushik, P. (2018). Stability analysis of some novel cytoplasmic male sterile sources of sunflower and their hybrids. Helia, 41(69), 153-200.

Webster, D. L., Benz, B. F., Blake, M., Lesure, R., McClung de Tapia, E., Sheets, P., \& Wendt, C. . (2011). Backward bottlenecks: Ancient teosinte/maize selection. Current Anthropology, 52(1), 0.

Widayati, S. (2018). Perkembangan Produksi Pakan Indonesia dan Prediksi Produksi 2019. .Disampaikan Pada Seminar Nasional Bisnis Peternakan
Asosiasi Obat Hewan Indonesia. Jakarta, 22 November 2018.

Wills, D. M., Whipple, C. J., Takuno, S., Kursel, L. E., Shannon, L. M., Ibarra, J. R. J., \& Doebley, F. (2013). From many, one: genetic control of prolificacy during maize domestication. Plos Genetics, 9, 1-12.

https://doi.org/10.1371/journal.pgen.1 003604.g001

Yang, L., Yang, C. . J., Cheng, Q., Xue, W., \& Doebley, J. F. (2016). Mapping Prolificacy QTL in Maize and Teosinte. Journal of Heredity, 107(7), 674-678. 